\title{
Growing Trends of Using Mobile in English Language Learning
}

\author{
Asma Abdul Aziz \\ Department of Humanities, \\ 9 Khwaja Fareed University of Engineering \& IT, \\ 10 Rahim Yar Khan, Pakistan \\ Mehmood UI Hassan \\ Department of Humanities \\ Khwaja Fareed University of Engineering \& IT, \\ 22 Rahim Yar Khan, Pakistan \\ Dr Hisham Dzakiria \\ School of Langauge, \\ Civilization and Philosophy, \\ Universiti Utara Malaysia \\ Qaisar Mahmood \\ School of Langauge, \\ Civilization and Philosophy, \\ Universiti of Utara Malaysia
}

Doi: 10.2478/mjss-2018-0132

\begin{abstract}
The study explores growing trends of using mobile in English language learning among higher secondary school learners in Pakistan. A survey is conducted to collect data from randomly selected students in district Okara (Punjab), Pakistan. Questionnaire based on five likert scale used to collect quantitative data. Analysis done on SPSS, to acquire mean score and frequency analysis reveals that higher secondary school students of English have great tendency for using mobile to learn English. Besides Students' perception as obtained from survey prove that using mobile for English language learning makes their job easy and they are able to develop their listening and communicative habits. Findings of this study also reveal that using mobile for English language learning makes the students, independent and self-evaluator.
\end{abstract}

Keywords: Android, mobile, trends, secondary, EFL student

\section{Introduction}

The use of technology in education is very beneficial for teachers and for those who are learning a foreign language. The significance of technology is seen in almost every step of our lives. Communication become so easy because the people in different parts of the world become closer to each other by some latest technologies like internet, web and mobile devices such as iPhone, Personal Digital Assistant (PDA's) etc (Sarica \&Cavus, 2008). Powerful internet connections and Web based technologies provide a range of new potentials for the improvement of educational 
technology. English is the global and an ideal language for expression of feelings that can be understood by all around the world. Nowadays students learn easier and faster because of the use of technology in educational institutions and have the chance of becoming specialists in technology also. It is important because students become willing to learn English by the use of technology. It is quite clear that English has become a necessity today. 1 million students participated in web- based courses in 1996 of higher education and estimated 3 million in 2000 (Edelson, 1998). Web based learning is developing in information technology for the interactive, learner-centered, efficient and flexible e-learning environments (Khan, 2005). Internet and Web based technologies are powerful source for new possibilities and latest developments for learners and teachers. They can learn a lot through cell phones, iPod, online quizzes and tests, blogs, instant messenger, internet telephone Skype, e-mails.

\subsection{Use of Mobile Devices}

Now world has been revolutionized over the years with the development of technology. Use of mobile in learning process is being use for a few years. First advantage of mobile learning for students is that they can use IT wherever and whenever they want to use it. They can also use other technological devices like PDA's. Mobile learning is also characterized as any skill or service that regardless of location and time provides educational content and electronic information which helps in attainment of knowledge (Lehner \& Nosekabel, 2002).Vavoula and Sharples (2002) also suggest three ways in which learning can be regarded learning through mobile in terms of space, in different areas of life and with respect to time. The can inferred by these definitions that, learners of foreign language can utilize mobile learning system at any time and at any where they need it. So, the service of mobile phones become most popular among people especially learners and teachers of foreign language.

\subsection{Popularity of Cell Phones and iPhone}

Hedge (2008) states that in this age of science and technology, the majority of the learner possesses Android sets and mobile phones for a wide variety of purposes. The most popular use of mobile phones is that learners can learn vocabulary from the dictionary of their mobile phone and for that purpose they can feed or install any suitable dictionary from the internet. This proves very helpful in searching and learning new words with exercises in English. With the help of mobile phone students can ask questions in the form of short questions and teachers can give answer and feed back with the use of send Short Message Service (SMS). Furthermore, Mobile phones are very effective to exchange voice messages, small web pages, e-mails and it is very effective to do exercises from that small web pages. The study of Cooney and Keogh (2007) in Ireland's capital city Dublin, the study investigate the use of m-learning system which was deployed with the aim of school-based oral assessment and learners' self-assessment and to facilitate them to increase their' communicative competence. This also has the purpose to learn Irish with fun with the support of web-chat and mobile phone. The m-learning system becomes popular with teachers and students alike because of its usefulness. Another project related to the use of mobile phones in language learning was conducted by the Stanford Learning Lab. (Brown, 2001). Specifically, they utilize both voice and email with mobile phones. These programs included quizzes, vocabulary practice, access to live talking tutors and word and phrase translations. It is proved by their results that mobile phones were useful for quiz delivery in small chunks with the automated or computerized voice vocabulary lessons had great effect on students' (Thornton \& Houser, 2002). On the other hand, i-phones present more pleasurable and interactive language learning atmosphere for students. Students with the help of a native speaker can construct their vocabulary and improve their pronunciation skills because they can record their voices to compare their own pronunciations and accent with that of a native speaker. 


\subsection{Use of Skype}

With the help of Skype, learners can talk with their teachers, instructors and with their fellows far away. Skype is a new and the powerful technology which fulfils the teaching and language learning needs (Wu, 2005). Learners of foreign language can speak with native speakers of that language. Learners of foreign language can also evaluate their pronunciation with those of native speakers. It is very effective for speaking skill and can be improved after using this application. This is also very economical for learners and teachers because they do not have to pay extra amount for this except the payment for internet access.

\section{Statement of the Problem}

Learning English in Pakistan has been a challenge for EFL students in Pakistan. Students are facing lot of problems in learning English. Mobile technology may be a great boon if properly used for learning purposes particularly learning a foreign language. Moreover, use of mobile technology is increasing day by day among students because of its significance for the improvement of vocabulary in English language. SMS, YouTube lessons, Mobile Assisted conducting Tests and various Apps may be self-drives in the acquisition of English if EFL students properly monitored and guided towards using mobiles for educational purposes.

\subsection{Objectives}

Following objectives were set in this study:

- To find out students' perceptions towards using Android Mobiles in improving day to day English vocabulary.

- To investigate whether less use of mobile results' in loss of vocabulary in English language.

- To investigate whether growing trend of using addressing sentences in English language through mobile apps' SMS is increasing for communicative purpose.

\section{Methods}

The population of this current research study was all the higher secondary School students Okara in Punjab, Pakistan. The sample for this study was comprised conveniently selected and accessible 180 students enrolled in second year from English department. A validated questionnaire designed on Likert Scale model was administered among the students of which 80 were female and 100 were male .The designed questionnaire had two aspects: the first aspect was concerned with the usefulness of Mobile for English language learning and the second component dealt with the liking of students towards Social media Apps. All calculations were made using SPSS version 22, by applying one sample t-test.

Table 1: EFL Students' Perceptions towards Use of Mobile

\begin{tabular}{|l|c|c|c|}
\hline \multicolumn{1}{|c|}{ Statements } & $\bar{x}$ & $S D$ & $t$ \\
\hline EFL Students' Perceptions towards Use of Mobile & $\mathbf{3 . 6 5}$ & $\mathbf{0 . 6 3}$ & $\mathbf{1 4 . 9 2}$ \\
\hline 1.Which app of social media do you like more? & 4.22 & 0.801 & 17.78 \\
\hline 2. How long do you use social media on android mobiles daily? & 3.71 & 1.133 & 11.26 \\
\hline 3.use of social media on Mobile you to improve your English vocabulary & 3.57 & 1.121 & 9.138 \\
\hline 4. English will contribute to self-development & 3.57 & 0.867 & 12.96 \\
\hline 5.use of social media on mobile has made you well aware of English & 3.70 & 1.172 & 9.799 \\
\hline 6. using social media on mobile enables to learn conversational sentences & 4.13 & 0.879 & 14.86 \\
\hline 7.social media on mobile should be used for English language learning & 3.61 & 1.311 & 6.623 \\
\hline
\end{tabular}

Test value $=3, \mathrm{df}=183, \mathrm{P}=0.000$ 
Table 2: EFL Students' Perceptions towards Mobile Apps

\begin{tabular}{|l|c|c|l|}
\hline Statements & $\bar{x}$ & $S D$ & $t$ \\
\hline Students' Perceptions towards Mobile Apps & $\mathbf{3 . 8 4}$ & $\mathbf{0 . 4 8 2}$ & $\mathbf{1 6 . 0 0 4}$ \\
\hline 8. Which app of social media do you like more? & 3.55 & 1.114 & 3.885 \\
\hline 9. How long do you use social media on android mobiles daily? & 3.57 & 1.136 & 3.876 \\
\hline 10. that use of social media on mobile helps you to improve your vocabulary & 3.79 & 1.014 & 7.227 \\
\hline 11. I think that I could learn very good English by using mobile apps & 4.34 & 1.021 & 15.538 \\
\hline 12. Mobile Apps are very helpful improving implicit knowledge of L2 & 4.42 & 0.749 & 19.123 \\
\hline
\end{tabular}

Test value $=3, \mathrm{df}=183, \mathrm{P}=0.00$

\section{Discussion}

This study explored the growing trends of using mobile in English language learning. Analysis of the data revealed that the mean score about the use of social media is 4.22 that is the evidence of students' awareness about the use of social media .They like to use face book because this is most popular app among them. Mean score related to time spent in using apps is 3.71 which mean that most of the students spend almost one hour daily in using face book which is helpful for learning English language. They think that with the help of mobile, they can use social media which is the cause of improving their vocabulary. The mean score about the improvement of their vocabulary is 3.57 which also show that they can get the chance to improve their vocabulary of day to day life. The mean score 3.57 reveals the awareness about the use of android mobiles and they are well aware about the use of mobile apps especially for the use of English language. Students consider mobile as tool for information. Mobile touch-screen technologies now become an educational tool for new generation. Learners can have access to this wealth at any time. Students can now use English language sentences by themselves because they use to give comments on one another on face book. The mean score 3.70 regarding impact of mobile use on speaking also shows that their speaking skill is also improving by the use of Skype and other devices available on their cell phones. The findings of the current research are much supported by El-Hariry's (2015) research about the usefulness of mobile. He explores that mobile devices are used dynamically in learning activities. His research concludes that moderate use of mobile phones may bring about much interest among EFL learners and makes the learning process easier by helping them to spiral up their self-esteem and self- confidence. These technologies are helpful in individual learning. With the advent of technology, learning of English language is becoming easier and faster. Another research by Nalliveettil \& Alenazi (2016) in Saudi Arabia about the impact of mobile phones on English language learning strengthens the effectiveness of the current research. The findings of this study reveal that peoples wish to have all their learning material on their mobile phone and is it is not only enjoyable but also enhances the motivation level of students. Almost everyone has a mobile set including students and teachers. So, there is no problem of time and space to learn language only after attending the long lectures in a language centre. Mobiles have become a good source for learning English language and mean score 3.20 about increasing trend among EFL learners also reveals that students now want to learn English language with great fun and through interesting quizzes. Means score 4.17 regarding availability of slides, lecture notes, and Practice quizzes on mobile phones reveals that learners find great interest in learning English if they find puzzles, quiz practices and other notes or helping materials available to them 24 hours on mobiles. Upon the same flow of similar approach was adopted by Saricaa \& Cavusb (2009) in their study about the new trends in English learning. This research reveals that it is helpful and effective if teachers write notes and print out to distribute to the learners. But it can be more helpful and more effective if teachers give online feedbacks to their students without using pencils to mark the option. This research proved that some of them started just like a game. Most of the learners learnt the use of new words by using what's app. The mean score about the use of what's app is 3.61 which show that they learn vocabulary by the use of what's app. It is also said that they can learn new words through what's app. In the current study, mean score 3.55 about less use of Apps on mobile shows that if students give up the using what's app, they think that their vocabulary becomes weaker due 
to the disconnection of social media. Mean score 3.57 about less connecting with social media proves that the less use of social media becoming a sole cause of a hurdle in learning English. The students' perceptions prove that social media is becoming a fashion of the day to on mobile apps for daily communication. To add more on current learning environment, Mean score 3.79 on tendency of using mobile apps reveals the fact that people have greater tendency to use what's app and Skype for communication with their relatives, friends and fellows. This tendency among learners is growing rapidly day by day which has further rectified with mean score 3.6 revealing the growing popularity of the use of mobiles to improve their vocabulary related to English language.

\section{Conclusion}

Learning of a language is not limited in the classroom or during lecturer time. It should not stop after the end of lecture time or after the teacher's presence. Present time is the age of Technology so, technological devices should also be used by teachers and learners. Learners and teachers can interact with the help of different devices. The most popular device which is growing day by day is the use of mobile devices. This is most admired and popular device among students because it is very useful for both teacher and student. The mobile based language teaching and learning activities are also popular because of interesting and enjoyable. Students never get bore and become successful to learn new vocabulary. The use of mobile for learning English language is growing day by day. Students know about the use of mobile technology and almost every student uses social media and face book at least one hour a day. It also becomes lesser if they give up the use of face book on mobile. Students' vocabulary for communication has been improved with the help of social media. They also participate in language learning quiz to know new words of English language.

\section{References}

Brown, S., Hu, N., Castelli-Gair Hombria, J. (2001), Identification of the first invertebrate interleukin JAK/STAT receptor, the Drosophila gene domeless. Curr. Biol. 11(21): 1700--1705.

Cooney, G., \& Keogh, K. A., (2007), Use of mobile phones for language learning and assessment for learning. A Pilot Project St. Johns, Beamore Road, Drogheda, Co. Louth, Ireland National Council for Curriculum and Assessment. Retrieved on 2 January 2007 from www.ncca.ie.

El-Hariry, N. A (2015), Mobile Phones As Useful Language Learning Tools. European Scientific Journal. Vol.11 (16), 298-317.

Edelson, P. J. (1998), the organization of courses via the internet, academic aspects, interaction, evaluation, and accreditation. National Autonomous University of Mexico, Mexico City

Hedge T. (2008), Teaching and Learning in the Language Classroom. Oxford: Oxford University Press.

Khan, B. H., (2005), Managing e-learning: Design, delivery, implementation, and evaluation. Hershey, PA: Information Science Publishing retrieved on 6th January from http://BooksToRead.com/elearning)

Lehner, F., \& Nosekabel, H., (2002), the role of mobile devices in e-learning first experience with e-learning environment. Wireless and Mobile Technologies in Education Proceedings. IEEE International Workshop, $103-$

Nalliveettil, G.M. \& Khaled-Alenazi, T.H (2016), the Impact of Mobile Phones on English Language Learning: Perceptions of EFL Undergraduates. Journal Of Language Teaching and Research .Vol. 7(2), 264-272.

Saricaa, G.N. \& Cavus, N. (2009), New trends in 21st Century English learning. North Cyprus Procedia Social and Behavioral Sciences. Vol.1, 439-445

Sarica, G., \&Cavus, N., (2008), Web based English language learning, presented at the 8th International Educational Technology Conference, Anadolu University, 6-9 May, Eskiehir, Turkey.

Thornton, P., \& Houser, C. (2001), Learning on the move: Foreign language vocabulary via SMS. ED-Mdia Proceedings, 1846-1847. Norfolk, Virginia: Association for the advancement of computing in Education.

Wu, W. S. (2005), Web-based English learning and teaching in Taiwan: Possibilities and challenges. Paper presented at The First Hsiang-shanarea Intercollegiate International Conference on English language teaching. Chung Hua University, Hsuan Chuang University, and Yuanpei University of Science and Technology, Hsinchu, Taiwan. Taipei: Crane Publishing, and Luke Swart. 